\title{
INHERITANCE OF NUMBERS OF LATERAL PLATES AND GILL RAKERS IN GASTEROSTEUS ACULEATUS
}

\author{
D. W. HAGEN* \\ College of Fisheries, University of Washington, Seattle, Washington 98195
}

Received 23.v.72

\begin{abstract}
SUMmary
Heritabilities for lateral plates in Gasterosteus are $0.50 \pm 0.043$ at $21^{\circ} \mathrm{C}$. and $0.83 \pm 0.033$ at $16^{\circ} \mathrm{C}$. for Lake Wapato stocks, and $0.84 \pm 0.039$ at $21^{\circ} \mathrm{C}$. for five other populations. The estimate for gill rakers from Lake Wapato is $0.58 \pm 0.056$ at $21^{\circ} \mathrm{C}$. In general, the two sexes of offspring do not differ in heritabilities; maternal effects apparently are not present. There is evidence that the asymmetry of plates has a large genetic component. The heritability is estimated at $0 \cdot 63 \pm 0 \cdot 16$. Sex ratio varies widely among laboratory-reared families and there is a significant excess of females in the field. No effects of temperature or density on sex ratio were found.
\end{abstract}

\section{Introduction}

Since the classic monographs of Bertin (1925) and Heuts (1947a) the remarkable variability of the threespine stickleback (Gasterosteus aculeatus) has attracted attention, particularly the variability in number of lateral plates and gill rakers (Hubbs, 1929; Heuts, 1947a, b, 1956; Lindsey, 1962; Munzing, 1963; Hagen, 1967; Miller and Hubbs, 1969). Almost all the variation in sticklebacks has been attributed to hybridisation and introgression (Munzing, 1963; Miller and Hubbs, 1969), but Hagen (1967), Hagen and McPhail (1970), and Hagen and Gilbertson (1972) found that hybridisation is largely confined to narrow zones in some coastal streams in the Pacific Northwest, America. Apparently introgression does not occur in the area, or at most is of minor importance as a cause of variation.

On the other hand, recent geographic surveys, work on natural populations and estimates of the intensity of selection in freshwater populations indicate that natural selection is a major cause of variation. Differential predation is probably one of the major selective agents acting on the variation among individuals for plates, whereas feeding specialisation in diverse habitats is a major selective agent acting on the variation in gill rakers (Hagen and Gilbertson, 1972, 1973; Moodie, 1972; Moodie, McPhail and Hagen, 1973; McPhail, unpublished data).

Implicit in all these studies is the assumption that these traits have a genetical basis. The purpose of this paper is to give estimates of heritability for number of lateral plates and gill rakers in Gasterosteus.

\section{MATERIALS AND MEthods}

Three plate morphs can be distingusihed in freshwater sticklebacks (leiurus), which we have simply named the low, partial and completely

\footnotetext{
* Present address: Biology Department, University of New Brunswick, Fredericton, New
} Brunswick, Canada. 
plated morphs. These three morphs have been illustrated and discussed elsewhere (Hagen and Gilbertson, 1972, 1973). They are controlled by major genes, and data on their genetics will be given in another paper. Within each morph the number of plates varies. For example, in freshwater sticklebacks that are monomorphic for the low plated morph, plate number varies from zero to 14 . It is this variation in plate number that concerns us here. Like plate number, the gill rakers on the first gill arch vary widely within and among populations. For example, the mean may be as low as 14.6 in some populations or as great as 21.7 in others (Hagen and Gilbertson, 1972).

The estimates of heritability for these traits are based on 95 families reared in the laboratory. Seventy-seven families were obtained with stocks from Lake Wapato in 1968 and 1969, and the heritabilities were estimated by the usual method of regression. The remaining 18 families were obtained in 1970 with stocks from Lake Quinault, Scatter Creek, Conner Creek,

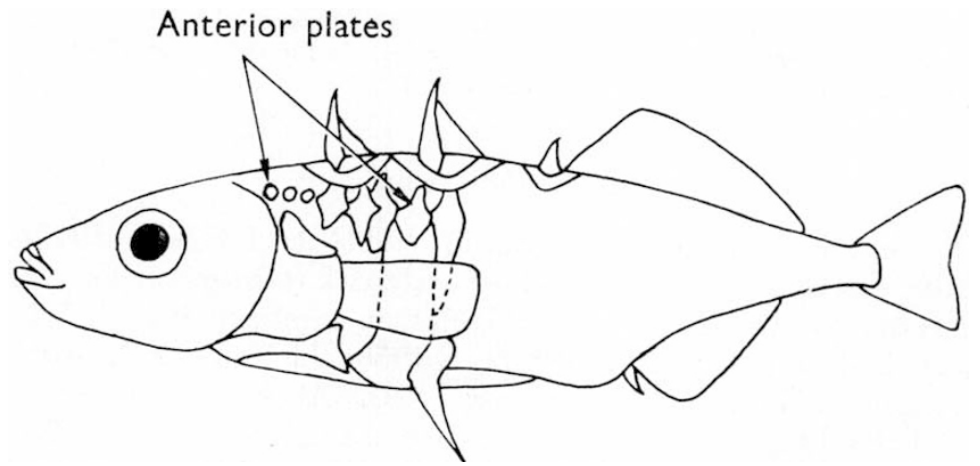

Fig. 1.-Lateral plates of Gasterosteus. Number varies from 3 to 14 in the populations used for heritability studies.

Chinacum Creek and the Samish River. All families were obtained by crossing parents from within localities (no crosses were made between localities), and the heritability was estimated by regression using offspring and parents from all five localities. Details of these populations are given in the papers of Hagen and Gilbertson $(1972,1973)$, and all are freshwater sticklebacks. The number of gill rakers in these populations varies from 12 to 26 , and the number of anterior plates (fig. 1) varies from 3 to 14 . These populations were chosen because of the great variation in number of plates and rakers in Lake Wapato, and because the others show large differences in mean number of plates among the populations.

Stocks of adults were gathered in the field during May and June when large numbers of gravid females and mature males are available, and they were transported to the laboratory in styrofoam containers. Matings between parents were made in the laboratory as soon as adults were collected. Eggs of mature females were artificially expressed into a small petri dish $(25 \mathrm{~mm}$.) containing a few drops of lake water by gently pressing the abdomen, and the testes of a male were immediately removed from a slit in the coelom and finely chopped with forceps in the dish. The clutch of eggs was then divided into about equal halves before the egg shell hardened, and half the clutch was discarded. 
The clutch size of the females used is greater than 40. Such large numbers of progeny in aquaria produce crowding and mortality. Falconer (1960) discusses the problems of experimental design for heritability estimates, as to whether one should use few large families or many small ones with the available facilities. Sampling error of the estimate will depend upon the magnitude of the heritability, but even with low heritabilities a large number of families each of about five progeny will give a reasonably precise estimate. In fact, most of the families I obtained with half clutches were much greater than this and none was less than eight.

Families were reared as uniformly as possible, each in 61-litre aquaria holding lake water obtained from a flow system in the laboratory and pumped from Lake Washington. Each aquarium had an active airstone and a charcoal filter (Dynaflow magnetic), and were on aquarium shelves with neon tubes (Gro-lux) suspended $22 \mathrm{~cm}$. above. The photoperiod was kept at 14 hours of light each day. Newly hatched fry were fed crushed

TABLE 1

Means and variances for number of plates and gill rakers of male and female Gasterosteus, Lake Wapato, and tests of significance for differences in variance between sexes

\begin{tabular}{|c|c|c|c|c|c|}
\hline & & $\mathcal{N}$ & $\bar{X}$ & $V$ & $F$ \\
\hline $\begin{array}{l}\text { Lateral plates } \\
\left(21^{\circ} \mathrm{C} .\right)\end{array}$ & $\begin{array}{l}\text { ơơ } \\
\text { 옹 }\end{array}$ & $\begin{array}{l}463 \\
495\end{array}$ & $\begin{array}{l}14 \cdot 80 \\
14 \cdot 76\end{array}$ & $\left.\begin{array}{l}9 \cdot 61 \\
8 \cdot 24\end{array}\right\}$ & 1.17 (N.S.) \\
\hline $\begin{array}{l}\text { Lateral plates } \\
\quad\left(16^{\circ} \mathrm{C} .\right)\end{array}$ & $\begin{array}{l}\text { 주 } \\
\text { 우우 }\end{array}$ & $\begin{array}{l}617 \\
669\end{array}$ & $\begin{array}{l}16 \cdot 26 \\
16 \cdot 78\end{array}$ & $\left.\begin{array}{l}26 \cdot 01 \\
30 \cdot 14\end{array}\right\}$ & $1 \cdot 16$ (N.S.) \\
\hline $\begin{array}{r}\text { Gill rakers } \\
\left(21^{\circ} \mathrm{C} .\right)\end{array}$ & $\begin{array}{l}\text { ô } \\
\text { 우 }\end{array}$ & $\begin{array}{l}245 \\
231\end{array}$ & $\begin{array}{l}18 \cdot 93 \\
19 \cdot 14\end{array}$ & $\left.\begin{array}{l}3.53 \\
3.92\end{array}\right\}$ & 1.11 (N.S.) \\
\hline
\end{tabular}

infusoria tablets (Longlife). After 3 days they were fed nauplii of brine shrimp (Longlife) twice daily for 6 weeks, and thereafter were fed live tubifex worms.

Offspring of parents collected at Lake Wapato in the spring of 1968 were reared at room temperature. As measured by constant temperature recorders (Bristol Recording Thermometers) in aquaria this was $21{ }^{\circ} \mathrm{C} . \pm 0.8$ during the period of development of plates and gill rakers (up to $28 \mathrm{~mm}$., see below). Offspring from Lake Wapato parents collected in 1969 were reared at $16^{\circ}$ C. \pm 0.5 by placing aquaria in large plastic troughs $(2.5 \mathrm{~m}$. long by $0.8 \mathrm{~m}$. wide) filled with water. Water temperature in the troughs was controlled by refrigeration units (Min-O-Ciool, Model D1-100, Frigid Units, Inc.). When fry reached a size of $28 \mathrm{~mm}$. or more they were transferred to the aquarium shelves at room temperature, because number of plates and gill rakers are then fully developed. In 1970 parents were collected from the five populations mentioned, and their progeny were reared at room temperature $\left(21^{\circ}\right.$ C. $\left.\pm 0 \cdot 8\right)$ like those from Lake Wapato. These temperatures are well within the range of those recorded at nests of males in the field.

Counts of gill rakers and plates were made according to the criteria of Hagen and Gilbertson (1972). All gill rakers on the first gill arch were counted, but on the left side only. Plates were counted on both sides of each individual and were summed between sides, so counts shown in the tables will in general be twice those usually given elsewhere. 
Plate and raker counts were usually made on progeny when they had grown to sexual maturity, at about 7 months and a size of 35 to $44 \mathrm{~mm}$. But in some instances individuals or entire families died of disease (Ichthyophthirius) or of unknown causes. To make counts reliably on such individuals we must know when development of the trait is complete. This is difficult to estimate for rakers as counts cannot be made on live fish. But progeny of about $25 \mathrm{~mm}$. size have counts like those of their parents and there is no suggestion of missing or undeveloped rakers along the gill arch (sample of 388 ). Counts of plates were made on more than 600 live progeny when they had grown to $28 \mathrm{~mm}$. by placing individuals on a moist cushion of cotton under a binocular dissecting scope. They were then quickly returned to their aquaria, and counts were repeated 4 months later at sexual maturity. The discrepancy in counts was less than 1 per cent. This error is about the same as the observational error we obtained from repeated counts on adults (Hagen and Gilbertson, 1973). Frequencies of the three plate morphs scored in a comparable sample showed no differences between fry and adults. So apparently development of plates and rakers is complete at a size of at least $28 \mathrm{~mm}$. in these populations, and I restricted counts to individuals of $29 \mathrm{~mm}$. or greater.

\section{ANAlysis AND Discussion}

Heritability $\left(h^{2}\right)$ is defined in the "narrow" sense as the ratio of the additive genetic variance to the total phenotypic variance. This may be evaluated either by extracting variance components from the correlations among relatives or by regression (Falconer, 1960). With the large number of families available $I$ have employed the regression method.

TABLE 2

Gill raker number for parents and offspring of Gasterosteus from Lake Wapato; offspring reared at $21^{\circ} \mathrm{C} . \pm 0 \cdot 8$

\begin{tabular}{|c|c|c|c|c|c|}
\hline \multicolumn{2}{|c|}{$\overbrace{}^{\text {Parents }}$} & \multicolumn{3}{|c|}{ Offspring } & \multirow{2}{*}{$\begin{array}{c}\text { Number of } \\
\text { offspring }\end{array}$} \\
\hline$\pi$ & $q$ & 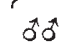 & qO & Mean & \\
\hline 20 & 16 & $19 \cdot 20$ & $19 \cdot 40$ & $19 \cdot 30$ & 10 \\
\hline 17 & 17 & $18 \cdot 20$ & $17 \cdot 67$ & $18 \cdot 00$ & 8 \\
\hline 19 & 19 & $18 \cdot 88$ & $20 \cdot 00$ & $19 \cdot 25$ & 12 \\
\hline 18 & 16 & $17 \cdot 85$ & $18 \cdot 50$ & $18 \cdot 13$ & 23 \\
\hline 20 & 20 & $20 \cdot 67$ & $21 \cdot 50$ & $21 \cdot 22$ & 9 \\
\hline 17 & 17 & $18 \cdot 38$ & $18 \cdot 00$ & $18 \cdot 25$ & 24 \\
\hline 20 & 16 & $17 \cdot 57$ & $18 \cdot 67$ & $18 \cdot 23$ & 35 \\
\hline 17 & 18 & $17 \cdot 40$ & $18 \cdot 37$ & $18 \cdot 02$ & 42 \\
\hline 21 & 22 & $21 \cdot 53$ & $21 \cdot 65$ & $21 \cdot 61$ & 38 \\
\hline 16 & 14 & $16 \cdot 33$ & $15 \cdot 60$ & $17 \cdot 82$ & 8 \\
\hline 17 & 18 & $18 \cdot 67$ & $18 \cdot 44$ & 18.56 & 18 \\
\hline 17 & 17 & $18 \cdot 00$ & 18.09 & $18 \cdot 06$ & 17 \\
\hline 16 & 13 & $16 \cdot 33$ & 15.88 & $18 \cdot 10$ & 17 \\
\hline 16 & 17 & $18 \cdot 00$ & $17 \cdot 00$ & $17 \cdot 44$ & 9 \\
\hline 18 & 19 & $18 \cdot 78$ & $19 \cdot 11$ & 18.93 & 41 \\
\hline 18 & 16 & $17 \cdot 88$ & $17 \cdot 75$ & $17 \cdot 83$ & 12 \\
\hline 21 & 16 & $19 \cdot 35$ & 19.94 & $19 \cdot 68$ & 59 \\
\hline 18 & 16 & $19 \cdot 33$ & $18 \cdot 20$ & 18.82 & 11 \\
\hline 17 & 21 & $19 \cdot 60$ & $19 \cdot 12$ & $19 \cdot 43$ & 23 \\
\hline 20 & 19 & $19 \cdot 57$ & $20 \cdot 09$ & $19 \cdot 70$ & 46 \\
\hline 24 & 26 & $23 \cdot 71$ & $22 \cdot 14$ & 22.93 & 14 \\
\hline
\end{tabular}


TABLE 3

Lateral plate number for parents and offspring of Gasterosteus from Lake Wapato; offspring reared at $21^{\circ} \mathrm{C} . \pm 0.8$ and $16^{\circ} \mathrm{C}$.

At $21^{\circ} \mathrm{C}$

\begin{tabular}{|c|c|c|c|c|c|}
\hline \multicolumn{2}{|c|}{ Parents } & \multicolumn{3}{|c|}{ Offspring } & \multirow{2}{*}{$\begin{array}{l}\text { Number of } \\
\text { offspring }\end{array}$} \\
\hline o & 우 & ठేరే & 우아 & Mean & \\
\hline 12 & 12 & 13.00 & $12 \cdot 00$ & $12 \cdot 67$ & 9 \\
\hline 14 & 16 & 14.42 & 14.33 & 14.37 & 27 \\
\hline 14 & 16 & $14 \cdot 40$ & 14.80 & $14 \cdot 60$ & 10 \\
\hline 14 & 14 & 13.83 & 13.74 & 13.77 & 31 \\
\hline 18 & 14 & $14 \cdot 60$ & $14 \cdot 17$ & 14.89 & 15 \\
\hline 14 & 12 & $13 \cdot 26$ & 13.40 & $13 \cdot 29$ & 24 \\
\hline 20 & 20 & 15.59 & $15 \cdot 43$ & $15 \cdot 53$ & 36 \\
\hline 16 & 22 & $15 \cdot 43$ & $15 \cdot 89$ & $15 \cdot 63$ & 62 \\
\hline 12 & 12 & $0 \cdot 00$ & 0.00 & $12 \cdot 66$ & 41 \\
\hline 17 & 14 & 13.86 & $14 \cdot 20$ & 14.09 & 88 \\
\hline 24 & 24 & $17 \cdot 30$ & $17 \cdot 20$ & 17.28 & 25 \\
\hline 17 & 14 & $14 \cdot 24$ & $15 \cdot 00$ & $14 \cdot 44$ & 34 \\
\hline 14 & 14 & 0.00 & $13 \cdot 70$ & $13 \cdot 70$ & 27 \\
\hline 28 & 12 & $0 \cdot 00$ & 14.56 & $14 \cdot 56$ & 9 \\
\hline 23 & 12 & $12 \cdot 00$ & $18 \cdot 27$ & $17 \cdot 88$ & 16 \\
\hline 16 & 17 & 0.00 & $15 \cdot 00$ & $15 \cdot 00$ & 7 \\
\hline 13 & 12 & $13 \cdot 25$ & 13.75 & $13 \cdot 50$ & 8 \\
\hline 14 & 13 & $12 \cdot 50$ & $14 \cdot 14$ & 13.78 & 9 \\
\hline 23 & 19 & $16 \cdot 20$ & $16 \cdot 00$ & $16 \cdot 12$ & 8 \\
\hline 14 & 14 & $14 \cdot 25$ & 13.50 & 14.00 & 12 \\
\hline 14 & 14 & $14 \cdot 28$ & 13.78 & 14.00 & 16 \\
\hline 8 & 8 & $12 \cdot 23$ & $13 \cdot 30$ & $12 \cdot 70$ & 23 \\
\hline 14 & 14 & $13 \cdot 33$ & 14.33 & $14 \cdot 00$ & 9 \\
\hline 16 & 11 & 13.06 & $14 \cdot 24$ & $13 \cdot 69$ & 39 \\
\hline 19 & 16 & $15 \cdot 81$ & $15 \cdot 75$ & $15 \cdot 79$ & 24 \\
\hline 11 & 9 & $13 \cdot 78$ & $12 \cdot 81$ & $13 \cdot 20$ & 35 \\
\hline 14 & 15 & 14.07 & $14 \cdot 30$ & $14 \cdot 21$ & 42 \\
\hline 14 & 15 & $14 \cdot 13$ & 14.43 & $14 \cdot 32$ & 38 \\
\hline 14 & 14 & 13.67 & $14 \cdot 20$ & $14 \cdot 00$ & 8 \\
\hline 15 & 12 & 13.89 & $13 \cdot 67$ & $13 \cdot 78$ & 18 \\
\hline 24 & 12 & $16 \cdot 67$ & 17.09 & 16.94 & 17 \\
\hline 28 & 28 & 21.78 & $24 \cdot 75$ & $23 \cdot 18$ & 17 \\
\hline 16 & 14 & 14.50 & $14 \cdot 80$ & $14 \cdot 67$ & 9 \\
\hline 13 & 24 & 17.83 & $16 \cdot 17$ & $17 \cdot 10$ & 41 \\
\hline 18 & 17 & $17 \cdot 38$ & $18 \cdot 75$ & 17.83 & 12 \\
\hline 14 & 14 & 13.85 & $13 \cdot 58$ & $13 \cdot 69$ & 59 \\
\hline 14 & 13 & 13.50 & $12 \cdot 20$ & 12.91 & 11 \\
\hline 12 & 18 & $15 \cdot 00$ & $16 \cdot 25$ & 15.43 & 23 \\
\hline 16 & 13 & 15.63 & 16.64 & $15 \cdot 87$ & 46 \\
\hline 8 & 14 & $10 \cdot 14$ & $12 \cdot 00$ & $11 \cdot 07$ & 14 \\
\hline
\end{tabular}

At $16^{\circ} \mathrm{C}$

\begin{tabular}{|c|c|c|c|c|c|}
\hline \multicolumn{2}{|c|}{ Parents } & \multicolumn{3}{|c|}{ Offspring } & \multirow{2}{*}{$\begin{array}{l}\text { Number } \\
\text { offspring }\end{array}$} \\
\hline t & o & $\Delta \sigma^{*}$ & 우아 & Mean & \\
\hline 18 & 14 & $15 \cdot 89$ & $15 \cdot 89$ & $15 \cdot 89$ & 18 \\
\hline 14 & 14 & $14 \cdot 70$ & 13.87 & $14 \cdot 20$ & 25 \\
\hline 15 & 28 & $20 \cdot 00$ & $19 \cdot 05$ & $19 \cdot 45$ & 33 \\
\hline 14 & 14 & $14 \cdot 00$ & $14 \cdot 06$ & $14 \cdot 04$ & 22 \\
\hline 12 & 14 & $13 \cdot 00$ & $13 \cdot 00$ & 13.00 & 29 \\
\hline 14 & 12 & $13 \cdot 72$ & $13 \cdot 88$ & $13 \cdot 80$ & 50 \\
\hline 16 & 24 & $21 \cdot 75$ & $19 \cdot 33$ & $19 \cdot 50$ & 10 \\
\hline 12 & 12 & $12 \cdot 00$ & $12 \cdot 14$ & 12.08 & 26 \\
\hline 14 & 12 & 13.52 & 13.58 & 13.55 & 78 \\
\hline 28 & 13 & $20 \cdot 00$ & $21 \cdot 39$ & $20 \cdot 78$ & 32 \\
\hline 14 & 29 & 18.96 & $19 \cdot 82$ & $19 \cdot 34$ & 50 \\
\hline 14 & 22 & $16 \cdot 44$ & 17.75 & 17.06 & 17 \\
\hline 15 & 14 & $14 \cdot 15$ & $14 \cdot 14$ & $14 \cdot 15$ & 47 \\
\hline 24 & 24 & $19 \cdot 76$ & $22 \cdot 78$ & $20 \cdot 97$ & 35 \\
\hline 14 & 28 & $20 \cdot 82$ & $20 \cdot 50$ & $20 \cdot 60$ & 68 \\
\hline 16 & 26 & $18 \cdot 09$ & $20 \cdot 17$ & $20 \cdot 52$ & 23 \\
\hline 12 & 12 & 12.59 & $12 \cdot 69$ & $12 \cdot 64$ & 56 \\
\hline 28 & 14 & $18 \cdot 40$ & $20 \cdot 41$ & $19 \cdot 32$ & 37 \\
\hline 14 & 13 & $13 \cdot 60$ & $13 \cdot 61$ & $13 \cdot 61$ & 84 \\
\hline 12 & 13 & $13 \cdot 00$ & 13.29 & $13 \cdot 14$ & 36 \\
\hline 14 & 12 & 13.07 & $11 \cdot 50$ & $12 \cdot 60$ & 20 \\
\hline 14 & 12 & $13 \cdot 50$ & $13 \cdot 10$ & $13 \cdot 24$ & 29 \\
\hline 26 & 14 & 17.90 & $19 \cdot 14$ & $18 \cdot 74$ & 31 \\
\hline 26 & 14 & $20 \cdot 43$ & $17 \cdot 20$ & $19 \cdot 08$ & 12 \\
\hline 21 & 12 & $17 \cdot 42$ & $21 \cdot 33$ & $18 \cdot 20$ & 15 \\
\hline 18 & 14 & $13 \cdot 60$ & $17 \cdot 28$ & $15 \cdot 75$ & 12 \\
\hline 19 & 12 & $16 \cdot 00$ & $16 \cdot 88$ & $16 \cdot 54$ & 13 \\
\hline 14 & 23 & $17 \cdot 00$ & $16 \cdot 69$ & $16 \cdot 85$ & 33 \\
\hline 16 & 13 & $14 \cdot 46$ & $13 \cdot 81$ & $14 \cdot 10$ & 29 \\
\hline 16 & 21 & $17 \cdot 60$ & $20 \cdot 25$ & $19 \cdot 23$ & 13 \\
\hline 19 & 14 & $16 \cdot 21$ & $16 \cdot 90$ & $16 \cdot 49$ & 73 \\
\hline 15 & 27 & 18.92 & $19 \cdot 00$ & $18 \cdot 96$ & 50 \\
\hline 14 & 28 & $18 \cdot 78$ & $24 \cdot 00$ & $20 \cdot 76$ & 29 \\
\hline 27 & 15 & 17.83 & $23 \cdot 00$ & $20 \cdot 18$ & 22 \\
\hline 24 & 12 & 18.41 & $18 \cdot 29$ & $18 \cdot 33$ & 72 \\
\hline 22 & 14 & $18 \cdot 32$ & $19 \cdot 22$ & $18 \cdot 85$ & 46 \\
\hline 8 & 10 & $9 \cdot 57$ & $9 \cdot 14$ & $9 \cdot 36$ & 14 \\
\hline
\end{tabular}

Several points should be mentioned before discussing the heritability estimates. First, most of the parents were mated randomly as the number of plates and gill rakers were counted after the crosses were made. However, there are two sources of correlation between parents. Eight of the matings from Lake Wapato (four at each rearing temperature) were between parents deliberately chosen for extremes of high and low plate counts. These positive assortative matings were made to decrease the sampling error of the regression of offspring on midparent values. Another source of correlation comes from the parents collected from the other five populations. They will be more alike than randomly chosen ones because there are large 
TABLE 4

Lateral plate number for parents and offspring of Gasterosteus from five localities in Washington; offspring reared at $21^{\circ} \mathrm{C} . \pm 0.8$

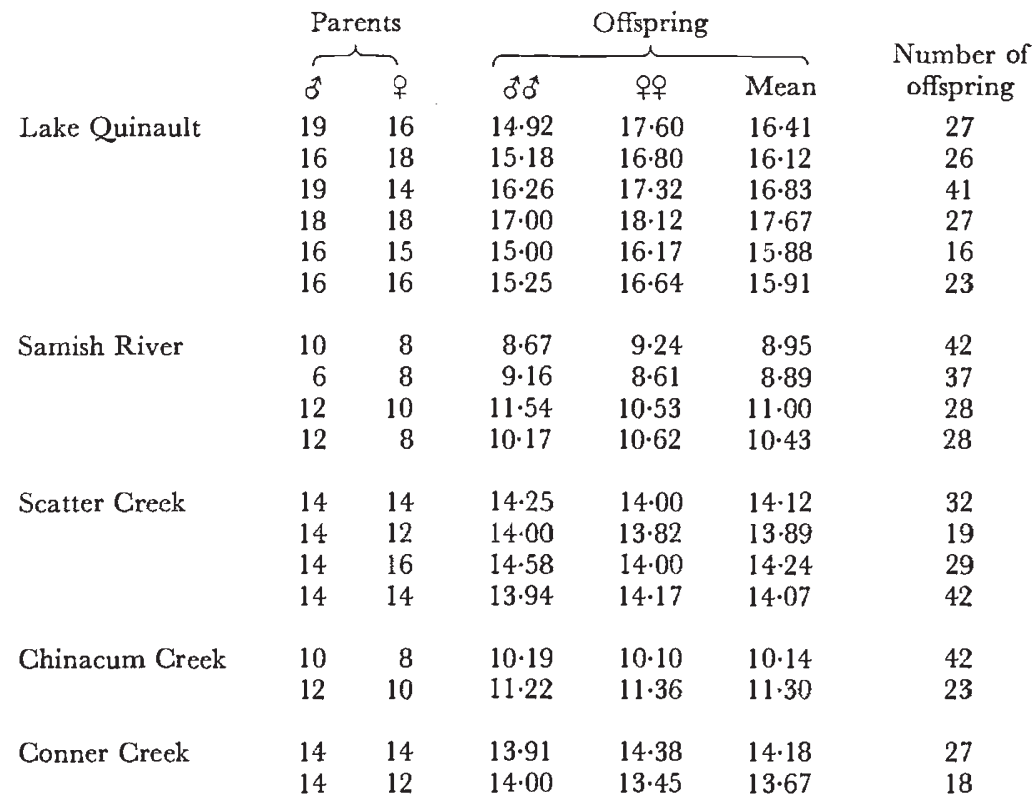

differences in mean plate number among these populations. This correlation among parents will not affect the regression (Falconer, 1960).

Second, the regression of means of offspring on midparent will be a valid estimate of the heritability only if the variances for the traits are equal in the two sexes (Falconer, 1960), which they are for both plates and gill rakers (table 1). Third, in estimating heritability from regression the question of how to treat variable family sizes arises. Methods of weighting families are discussed by Reeve (1955), but all have certain difficulties. I have given equal weights to all families; that is, no weighting is used.

The basic data for parents and offspring are set out in table 2 for gill rakers and in tables 3 and 4 for lateral plates. The heritabilities, shown in table 5, all have regressions that differ significantly from zero. The heritability of plates for the Wapato stocks at $16^{\circ} \mathrm{G}$. is considerably greater than that at $21^{\circ}$ C.; the two regressions differ significantly $\left(F_{1,74}=36.5\right.$; $\mathrm{P}<0.001)$. The heritability of plates obtained from the five populations and reared at $21^{\circ} \mathrm{C}$. is close to the estimate for Lake Wapato at $16^{\circ} \mathrm{C}$.

TABLE 5

Heritabilities $\left(h^{2}\right)$ for lateral plates and gill rakers of Gasterosteus, and results of analysis of variance testing for departure of the regressions from zero

\begin{tabular}{lccccc} 
& \multicolumn{5}{c}{ Standard } \\
& $\left(h^{2}\right)$ & error & d.f. & F & P \\
Plates, Wapato $\left(21^{\circ} \mathrm{C}.\right)$ & 0.50 & 0.043 & 1,38 & 137 & $<0.001$ \\
Plates, Wapato $\left(16^{\circ} \mathrm{C}\right.$. $)$ & 0.83 & 0.033 & 1,35 & 618 & $<0.001$ \\
Plates, among populations & 0.84 & 0.039 & 1,16 & 466 & $<0.001$ \\
$\quad\left(21^{\circ} \mathrm{C}\right.$. $)$ & & & & & \\
Gill rakers, Wapato $\left(21^{\circ} \mathrm{C}\right.$.) & 0.58 & 0.056 & 1,19 & 218 & $<0.001$
\end{tabular}


TABLE 6

Regressions $(b)$ of male and female offspring on midparent for lateral plates and gill rakers in Gasterosteus

\begin{tabular}{|c|c|c|c|c|c|}
\hline & & $\begin{array}{l}\text { Number of } \\
\text { families }\end{array}$ & $b$ & $\begin{array}{l}\text { Standard } \\
\text { error }\end{array}$ & $\begin{array}{l}\text { Confidence } \\
\text { limits }\end{array}$ \\
\hline Plates, Wapato $\left(21^{\circ} \mathrm{C}.\right)$ & 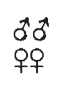 & $\begin{array}{l}37 \\
39\end{array}$ & $\begin{array}{l}0 \cdot 45 \\
0.52\end{array}$ & $\begin{array}{l}0 \cdot 053 \\
0 \cdot 057\end{array}$ & $\begin{array}{l}0.342 \leqq b \leqq 0 \cdot 560 \\
0 \cdot 290 \leqq b \leqq 0 \cdot 750\end{array}$ \\
\hline Plates, Wapato ( $16^{\circ} \mathrm{C}$.) & 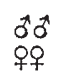 & $\begin{array}{l}36 \\
37\end{array}$ & $\begin{array}{l}0.75 \\
0.92\end{array}$ & $\begin{array}{l}0 \cdot 046 \\
0 \cdot 062\end{array}$ & $\begin{array}{l}0.654 \leqq b \leqq 0.842 \\
0.794 \leqq b \leqq 1.046\end{array}$ \\
\hline $\begin{array}{l}\text { Plates, among populations } \\
\left(21^{\circ} \text { C. }\right)\end{array}$ & 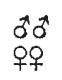 & $\begin{array}{l}18 \\
18\end{array}$ & $\begin{array}{l}0.74 \\
0.92\end{array}$ & $\begin{array}{l}0 \cdot 054 \\
0 \cdot 041\end{array}$ & $\begin{array}{l}0.632 \leqq b \leqq 0.848 \\
0.838 \leqq b \leqq 1.002\end{array}$ \\
\hline Gill rakers, Wapato $\left(21^{\circ} \mathrm{C}.\right)$ & $\begin{array}{l}\text { 10 } \\
\text { 옹 }\end{array}$ & $\begin{array}{l}21 \\
21\end{array}$ & $\begin{array}{l}0 \cdot 60 \\
0 \cdot 46\end{array}$ & $\begin{array}{l}0 \cdot 068 \\
0 \cdot 105\end{array}$ & $\begin{array}{l}0.465 \leqq b \leqq 0.737 \\
0.247 \leqq b \leqq 0.668\end{array}$ \\
\hline
\end{tabular}

There will be differences in gene frequency among populations and so we may expect the heritability obtained from the five populations to be greatest. When this estimate is compared with the heritability from Wapato at the same rearing temperature $\left(21^{\circ} \mathrm{C}\right.$.), the estimate for the five populations is considerably greater.

The regression of male and female offspring on midparent gives an estimate of heritabilities for the sexes (table 6). The sexes do not differ significantly (i.e. both regression coefficients fall within the two confidence limits), with the exception of the regressions for plates at $16^{\circ} \mathrm{C}$. for which the females have a significantly greater value $(\mathrm{P}<0.05)$. But we may take the previous heritabilities, for the sexes combined, as representative since the difference between sexes at $16^{\circ} \mathrm{G}$. is barely significant and the remaining values are not.

The male and female parents for most of the crosses differ in number of plates and rakers (tables $2,3,4$ ) so the regression of offspring on the male and on the female parent can be used to detect maternal effects (table 7). For plates none of the regressions on the two parents differs significantly. For gill rakers the regressions on the two parents do differ $(\mathrm{P}<0.05)$, but it is the regression on the male parent that has the greater coefficient. This suggests there are no maternal effects, which was upheld by an analysis of the means of offspring from reciprocal crosses (from tables 2, 3, 4).

The data also provide evidence on the heritability of asymmetry in plate number because about 37 per cent. of the parents differ in counts

TABle 7

Regressions (b) of offspring on male and female parent for lateral plates and gill rakers in Gasterosteus

\begin{tabular}{|c|c|c|c|c|c|}
\hline & & $\begin{array}{l}\text { Number of } \\
\text { families }\end{array}$ & $b$ & $\begin{array}{l}\text { Standard } \\
\text { error }\end{array}$ & $\begin{array}{l}\text { Confidence } \\
\text { limits }\end{array}$ \\
\hline Plates, Wapato $\left(21^{\circ} \mathrm{C}.\right)$ & $\begin{array}{l}0 \\
0 \\
+\end{array}$ & $\begin{array}{l}40 \\
40\end{array}$ & $\begin{array}{l}0.33 \\
0.36\end{array}$ & $\begin{array}{l}0 \cdot 047 \\
0 \cdot 056\end{array}$ & $\begin{array}{l}0.232 \leqq b \leqq 0.420 \\
0.244 \leqq b \leqq 0.472\end{array}$ \\
\hline Plates, Wapato $\left(16^{\circ} \mathrm{C}\right.$.) & $\begin{array}{l}\hat{0} \\
+\end{array}$ & $\begin{array}{l}37 \\
37\end{array}$ & $\begin{array}{l}0.39 \\
0.36\end{array}$ & $\begin{array}{l}0.080 \\
0.056\end{array}$ & $\begin{array}{l}0.225 \leqq b \leqq 0.548 \\
0.244 \leqq b \leqq 0.472\end{array}$ \\
\hline $\begin{array}{l}\text { Plates, among populations } \\
\left(21^{\circ} \text { C. }\right)\end{array}$ & $\begin{array}{l}0 \\
0 \\
+\end{array}$ & $\begin{array}{l}18 \\
18\end{array}$ & $\begin{array}{l}0.79 \\
0.75\end{array}$ & $\begin{array}{l}0 \cdot 071 \\
0 \cdot 069\end{array}$ & $\begin{array}{l}0.648 \leqq b \leqq 0.932 \\
0.612 \leqq b \leqq 0.888\end{array}$ \\
\hline Gill rakers, Wapato $\left(21^{\circ} \mathrm{C}\right.$. $)$ & $\begin{array}{l}\hat{0} \\
0 \\
0\end{array}$ & $\begin{array}{l}21 \\
21\end{array}$ & $\begin{array}{l}0.58 \\
0.40\end{array}$ & $\begin{array}{l}0.082 \\
0.064\end{array}$ & $\begin{array}{l}0.417 \leqq b \leqq 0.743 \\
0.275 \leqq b \leqq 0.513\end{array}$ \\
\hline
\end{tabular}


between sides. Matings between parents can be grouped into those with both parents symmetric, one parent asymmetric by one plate (a difference of one plate between sides), both parents asymmetric by one plate, and both parents asymmetric by more than one plate. The frequency of symmetric and asymmetric offspring in each group is then found. The difference is highly significant, asymmetric parents having a greater number of asymmetric progeny (table 8), which strongly suggests a rather large heritable component in asymmetry of plates. The estimation of heritabilities by regression is straightforward when the characters can be measured on a continuous scale, but this does not apply when the characters have a discontinuous distribution with an "all-or-none" classification. For example, nearly all the sticklebacks are symmetric for plate number, or they

TABLE 8

Lateral plates of Gasterosteus: number of symmetric and asymmetric offspring from parents with increasing degrees of asymmetry. Chisquare testing a difference in distribution of asymmetric offspring

\begin{tabular}{|c|c|c|}
\hline \multirow[b]{2}{*}{ Parents } & \multicolumn{2}{|c|}{ Offspring } \\
\hline & Symmetric & Asymmetric \\
\hline Symmetric & 992 & 163 \\
\hline $\begin{array}{l}\text { Asymmetric for one plate } \\
\text { (one parent) }\end{array}$ & 631 & 247 \\
\hline $\begin{array}{l}\text { Asymmetric for one plate } \\
\text { (both parents) }\end{array}$ & 49 & 66 \\
\hline $\begin{array}{l}\text { Asymmetric for more than one } \\
\text { plate (both parents) }\end{array}$ & 100 & 40 \\
\hline
\end{tabular}

are asymmetric with a difference of one plate between sides (table 8); the distribution is highly discontinuous. Falconer $(1965,1967)$ developed a method for estimating the heritability of characters having an "all-or-none" classification, and the method can be used to estimate the heritability of asymmetry. Since the parents are randomly sampled and randomly mated with respect to asymmetry of plates, the data required to estimate the heritability are the frequencies of symmetric and asymmetric progeny from the parents that are both symmetric: and those with one or both the parents asymmetric (table 8, with all asymmetric classes of parents grouped). Applying Method 2 of Falconer (1967; equation 4, pages 60 and 74) the heritability and standard error for asymmetry is $0.63 \pm 0 \cdot 16$. This is an estimate of the proportion of additive genetic variance.

There are significantly more female offspring and adults in Lake Wapato than there are males (Hagen and Gilbertson, 1973), and in the laboratoryreared offspring most clutches show a wide departure from an equal sex ratio although the overall ratio does not depart from equality (table 1). Lindsey (1962) gave evidence that temperature and density affected sex ratio in threespine sticklebacks. My clutches from Lake Wapato were reared at two temperatures and there are rather large differences in density among families, so I have analysed the data for effects of temperature and density 
on sex ratio by analysis of covariance (table 9 ). The results give no evidence that temperature or density effect the sex ratio.

Heritabilities for lateral plates and gill rakers in Lake Wapato and for lateral plates in five other populations are high. How far can we generalise the results? Heritabilities are of course specific for particular populations and for a specified set of environmental conditions. But all parents were collected from the field where they would experience large fluctuations in the environment during development, and so increase the environmental variance of the phenotype. Nevertheless, heritabilities of their offspring reared in the laboratory are high, so we may have confidence that similar values exist in these populations.

As mentioned, there is evidence for strong natural selection in populations of sticklebacks, from predation acting on number of plates and from

TABLE 9

Analysis of covariance for effects of rearing temperature $\left(21^{\circ} \mathrm{C}\right.$. and $16^{\circ} \mathrm{C}$.) and density on sex ratio in Gasterosteus. The dependent variable is the fraction of the female offspring (arcsine transformed)

\begin{tabular}{|c|c|c|c|c|c|c|}
\hline \multirow[b]{2}{*}{ Source of variation } & \multicolumn{2}{|c|}{ Total } & \multicolumn{2}{|c|}{ Due to regression } & \multicolumn{2}{|c|}{ Error } \\
\hline & $\begin{array}{l}\text { Degrees } \\
\text { freedom }\end{array}$ & $\begin{array}{c}\text { Sums } \\
\text { squares }\end{array}$ & $\begin{array}{l}\text { Degrees } \\
\text { freedom }\end{array}$ & $\begin{array}{l}\text { Mean } \\
\text { square }\end{array}$ & $\begin{array}{l}\text { Degrees } \\
\text { freedom }\end{array}$ & $\begin{array}{l}\text { Mean } \\
\text { square }\end{array}$ \\
\hline $21^{\circ} \mathrm{C}$. & 38 & $2 \cdot 7990$ & 1 & 0.0503 & 37 & 0.0743 \\
\hline $16^{\circ} \mathrm{C}$. & 36 & 0.4766 & 1 & 0.0158 & 35 & 0.0132 \\
\hline Within temperatures (pooled) & - & - & - & - & 72 & 0.0446 \\
\hline Regression coefficient & - & - & - & - & 1 & 0.0628 \\
\hline Common $\left(21^{\circ}\right.$ and $16^{\circ}$ C. $)$ & 74 & $3 \cdot 2761$ & 1 & $0 \cdot 0032$ & 73 & 0.0448 \\
\hline Adjusted means & - & - & - & - & 1 & 0.0344 \\
\hline Total & 75 & $3 \cdot 3194$ & 1 & 0.0121 & 74 & 0.0447 \\
\hline
\end{tabular}

Effects of family size on sex ratio: $21^{\circ}$ C. $F_{1,37}=0.677$ (n.s.); $16^{\circ}$ C. $F_{1,35}=1 \cdot 20$ (n.s.).

Effects of temperature on sex ratio: $F_{1,73}=0.768$ (n.s.).

feeding specialisation on gill rakers. The results here point to a large store of additive genetic variance present in these populations that is available for response to selection. The large temporal and abrupt spatial changes we have found for these traits are most probably a result of selection, acting in part through the agents of predation and food source, on this genetic component.

In a classic study of asymmetry in Drosophila melanogaster, Mather (1953) showed that the asymmetry in number of sternopleural chaetae is under genetical control, which is probably polygenic, and he also showed that the level of asymmetry increased with inbreeding. Also Beardmore (Ph.D. Thesis, Sheffield, 1956) and Thoday (1958) showed that asymmetry for sternopleural chaetae in Drosophila increased with directional selection. The number of plates and gill rakers of sticklebacks in Lake Wapato have been under directional selection, which is almost certainly a result of a recent colonisation from Lake Chelan (Hagen and Gilbertson, 1973). The high heritability found here for asymmetry of plates may in fact be a result of strong directional selection acting on this trait in Wapato, since we may expect the additive variance to increase as gene frequency rises to intermediate values.

Acknoweledgments.-I am indebted to Messrs David Semler, L. G. Gilbertson, and Miss Phyllis Drayton for their help in the field, and for their assistance with sticklebacks in the laboratory. Drs J. Felsenstein, P. O'Donald and Professors Bryan Clarke and C. C. Lindsey 
made helpful suggestions on the manuscript; especially I thank Dr P. O'Donald for calling to my attention some important references. The research was made possible by a grant from the National Science Foundation (GB-7686).

\section{REFERENCES}

BeARdmore, J. A. 1956. Ph.D: Thesis. University of Sheffield.

BERTIN, L. 1925. Recherches bionomiques, biometriques et systematiques sur les Epinoches (Gasterosteides). Ann. Inst. Oceanograph. Monaco, N.S., 2, fasc. 1.

FALCONER, D. s. 1960. Introduction to Quantitative Genetics. Oliver and Boyd, Edinburgh and London.

FALCONER, D. s. 1965. The inheritance of liability to certain diseases, estimated from the incidence among relatives. Ann. Hum. Genet., Lond., 29, 51-76.

FALCONER, D. s. 1967. The inheritance of liability to diseases with variable age of onset, with particular reference to diabetes mellitus. Ann. Hum. Genet., Lond., 31, 1-20.

HAGEN, D. W. 1967. Isolating mechanisms in threespine sticklebacks (Gasterosteus). 7. Fish. Res. Bd., Canada, 24, 1637-1692.

HAGEN, D. W., AND MCPHAIL, D. 1970. The species problem within Gasterosteus aculeatus on the Pacific coast of North America. J. Fish. Res. Bd. Canada, 27, 147-155.

HAGEN, D. W., AND GILBERTSON, L. 1972. Geographic variation and environmental selection in Gasterosteus aculeatus L. in the Pacific Northwest, America. Evolution, 26, 32-51.

HAGEN, D. W., AND GILBERTSON, L. 1973. Selective predation and the intensity of selection acting upon the lateral plates of threespine sticklebacks. Heredity (in press).

HeUTs, M. J. 1947a. The phenotypic variability of Gasterosteus aculeatus L. populations in Belgium. Meded. Kon. Vl. Akad. Wetensch, 25, 5-63.

HEUTs, м. J. 1947b. Experimental studies on adaptive evolution in Gasterosteus aculeatus L. Evolution, 1, 89-102.

HeUrs, M. J. 1956. Temperature adaptation in Gasterosteus aculeatus L. Publ. della Stazione Zool. die Napoli, 28, 44-61.

hubss, c. L. 1929. The Atlantic American species of the fish genus Gasterosteus. Occ. Pap. Mues. Zoo., Michigan, 20, 1-9.

LINDSEY, c. c. 1962. Experimental study of meristic variation in a population of threespine sticklebacks, Gasterosteus aculeatus. Canadian Jour. Zoo., 40, 271-312.

MATHER, K. 1953. Genetical control of stability in development. Heredity, 7, 297-336.

MILLER, R., AND HUBBs, c. 1969. Systematics of Gasterosteus aculeatus, with particular reference to intergradation and introgression along the Pacific coast of North America; a commentary on a recent contribution. Copeia, 52-69.

MOodIE, G. E. E. 1972. Predation, natural selection and adaptation in an unusual threespine stickleback. Heredity, 28, 155-168.

MOODIE, G. E. E., MCPHAIL, D., AND HAGEN, D. 1973. Experimental demonstration of selective predation on Gasterosteus aculeatus.

MUNZING, J. 1963. The evolution of variation and distribution patterns in European populations of the threespine stickleback, Gasterosteus aculeatus. Evolution, 17, 320-332.

REEVE, E. C. R. 1955. The variance of the genetic correlation coefficient. Biometrics, 11, $357-374$.

THODAY, J. M. 1958. Homeostasis in a selection experiment. Heredity, 12, 401-415. 